\title{
BATON ROUGE'S MUNICIPALCENTENARY
}

\author{
BY MILLEDGE L. BONHAM, JR. \\ Louisiana State University \\ DISCOVERY AND SETTLEMENT
}

$I^{\mathrm{T}}$ WAS on St. Patrick's day, 1699, that Pierre LeMoyne, sieur d'Iberville, discovered and named the site of the present capital of Louisiana. The date of the first settlement appears to be undiscoverable, but contemporary literature of $1719-1723$ speaks of it as if it had been there some time. Nothing of moment occurred at Baton Rouge, apparently, until 1763, when the Bourbon flag was replaced with the banner of St. George, and the post's name was changed to Fort Richmond. Sixteen years later, the only engagement of the Revolution-and that a slight one-occurred at Fort Richmond, between the Spanish troops of Governor Galvez, reinforced by American backwoodsmen, some Indians and a few negroes, on the one side, and the British garrison, under Colonel Dickson, on the other. The attackers were victorious, and the castles and lions of Spain floated over Baton Rouge until September 23, 1810. At that time, the Anglo-Americans in West Florida revolted against the rule of Spain, organized the "Republic of West Florida," and sent an "army" under General Philemon Thomas to take this fort at Baton Rouge. This was done, after a slight engagement as the result of which the "lone star" flag appeared for the first time in American history. The ensign of the West Floridians was a blue woolen field with one silver star in the center. When the Republic of West Florida sought annexation to the United States, President Madison said it was part of the Louisiana purchase, so Governor Claiborne extended his control over the region, replacing the blue woolen flag with "Old Glory." To this day, that part of Louisiana between the river, the lakes and the gulf is called "the Florida parishes."

Within less than half a century five flags-Bourbon, British, Spanish, West Floridian, American-had flown over Baton Rouge. Within the next half century, two more were to fly-state and Confederate. A second state flag, adopted after Reconstruction, made the eighth, while the tricolor of the French republic, which floated over New Orleans for three wreeks in 1803 , makes nine banners that waved over one part or another of Louisiana.

\section{INCORPORATION AND DEVELOPMENT}

Under whichever of the first five flags she might be, Baton Rouge was not a municipality, merely a settlement about a military post, the com- 
mandant of which prescribed such regulations as he deemed needful. The city of Baton Rouge came into being when Governor James Villeré signed, January 16, 1817, the statute authorizing the people of the town to elect five councillors, one of whom should be "magistrate," or mayor. Hence January 16, 1917, was the centenary of the incorporation of Baton Rouge.

Besides having eight flags float above her, Baton Rouge has witnessed many other historic events. The visit of Lafayette, in 1825, was but one of such visits by notabilities like Clay, Beauregard, Scott, etc. Zachary Taylor departed from Baton Rouge for Mexico, in 1845. The city became the capital in 1850 , while two years later a constitutional convention was held here. The secession convention met at Baton Rouge, in January 1861, seized the federal arsenal, and passed the ordinance of secession. Farragut captured the city, without a shot, in May 1862. In August, General Breckinridge, of the Confederate army, won a fruitless victory. He drove the Union forces from the outskirts of the city to the shelter of the gunboats, whose guns compelled him to withdraw. Federal headquarters were at New Orleans, Confederate at Shreveport. Not until after the régime of "carpetbagger and scalawag" was Baton Rouge again made the capital. This was done by the convention of 1879 .

Ten years before this, the plant of the state university at Alexandria had been destroyed by fire, so its domicile was changed to Baton Rouge, which is also the site of the state schools for the deaf, dumb and blind, for several private and church schools, while on its outskirts is the state industrial college for the colored.

Perhaps the largest of all the Standard Oil refineries was erected at Baton Rouge in 1909 . Four years later a constitutional convention met there and refunded the state debt. The year 1914 was signalized by the adoption of commission government, and the formation of the "organized charities," in which Roman Catholic, Protestant and Jew combine their resources to try to handle the problems of poverty and unemployment.

Meanwhile, in 1913, city and parish (county) had co-operated to establish a free fair, for which space for exhibits, admittance of visitors, and the like, are all gratuitous. By 1916 Baton Rouge felt that she had made so much history that it was time to collect and conserve some of it. For this purpose the "Historical Society of East and West Baton Rouge" was organized, with. General John McGrath, a veteran of Walker's first Nicaraguan expedition, and of the Civil war, at its head.

As oceangoing vessels can and do come to her docks, Baton Rouge did not rest until she was designated (1916) as a port of entry. Then she celebrated the occasion with a banquet. Seeking some other outlet for her enterprise and energy, she decided a modern Y. M. C. A. building was needed, so announcement was made that in the week beginning January 10,1917 , she would raise $\$ 50,000$ for that purpose. When the clock struck 8 , Tuesday evening, the $16 \mathrm{th}, \$ 62,450$ had been secured. 
A municipal abattoir had been established in the fall of 1915 , which was so successful that it reduced within six months its fees, and is still self-sustaining. At present, the plant is being enlarged.

\section{THE CENTENNIAL CELEBRATION}

Early in October, 1916, the historical society and the city commission began to discuss the best way to celebrate the centennial of the city's incorporation. Soon a committee was organized, representing, beside the two named, nearly every other organization of a religious, patriotic, social, business or fraternal nature. Tuesday, January 17, was the day selected. Because of a driving rain storm two items had to be omitted from the program; the "Jackies" of the U. S. torpedo-destroyers, Sterrett, Lamson, and Monaghan (then in the harbor) were to have opened the celebration with a parade. In the afternoon, the cadet corps of Louisiana State University was to hold a dress-parade, followed by a band-concert.

The first number of the actual celebration was a joint meeting of the Louisiana historical society, with the local society. A marble marker has been erected on the site of the old Spanish fort. This monument will be dedicated on the anniversary of the capture.

The climax of the centennial was a series of tableaux, given the same evening, representing various epochs in the life of the city. Backgrounds, poses, costumes, music, all combined to lend an air of verisimilitude. First Iberville was shown, discovering the site of the city; the orders of Redmen and Woodmen of the World staged this. Next, the Knights of Columbus showed Galvez's capture of the British fort, in 1779. The Odd Fellows then displayed the West Florida forces capturing it from the Spanish in 1810. Students of the university posed the first session of the first city council. Be it said in passing, that tradition tells us that one of the first councillors had been a pirate with Lafitte; another, a member of the West Florida Revolutionary junto, while a third was of Tory antecedents.

Lafayette's arrival in 1825 was shown by the Knights of Pythias. This was followed by a ball in his honor. Lafayette himself opened the minuet, the other dancers being young ladies and gentlemen of "town and gown." Fraternal orders, civilians and citizens next presented the scene of Zachary Taylor's notification of his nomination for president, in 1848. The curtain then rose upon the secession convention, engaged in signing the ordinance. This was arranged by the Daughters of the Confederacy, and was posed by Confederate veterans, or their descendants. Students of the university showed the removal of the institution to Baton Rouge, in 1869. The last picture, another "town and gown" combination, showed the return of the capital to Baton Rouge. 